\title{
Epidemiology, Transmission, Complications, Laboratory Diagnosis \& Management of Zika Virus Infection: A Systematic Review
}

\author{
SM Shamsuzzaman ${ }^{1}$, Shahin Ara Begum ${ }^{1}$, Sazzad Bin Shahid $^{1}$ \\ ${ }^{1}$ Department of Microbiology, Dhaka Medical College, Dhaka. \\ Submitted on: 20 September, 2015. Accepted on: 16 November, 2015
}

Key wards: Background, Clinical Features, Complications, Diagnosis, Prevention, Replication, Zika virus.

\section{Background}

Zika virus infection is a mild febrile viral illness transmitted by Aedes mosquito bite. ${ }^{1}$ This virus has been called Zika virus after the geographical name of the area from where the virus was first isolated. The Zika virus was first isolated in 1947 in Zika forest of Uganda in a pyrexial Rhesus monkey during a study of the transmission of wild yellow fever. ${ }^{2}$ It was first isolated from humans in 1952, in Uganda and Tanzania., ${ }^{2,3}$ In 1968 the virus was detected in human samples in Nigeria. ${ }^{4}$ Prior to 2015, outbreaks of Zika virus infection have been recorded in Africa, the America, South East Asia and the Pacific Islands. ${ }^{5,6}$ Guillian-Barrie syndrome has linked to Zika virus infection was reported in an outbreak in French Polynesia. ${ }^{6,7}$ In 2015, Brazil reported that there is an association between Zika virus infection and microcephaly with several thousands of microcephaly with some deaths. ${ }^{8,9}$

\section{Epidemiology}

Epidemiological studies showed that the virus has circulated in humans between 1951 and 1981 in Africa and Asia ${ }^{6,7}$ A sero-survey involving residents of multiple areas of Uganda revealed that $6.1 \%$ sero-prevalence of antibodies against Zika virus, which suggested that human infection was frequent. ${ }^{7,10}$ The Zika virus infection reported in Nigeria in 1954 and during that time a few outbreaks have been reported in tropical Africa and in some areas in Southeast Asia. ${ }^{2,11}$ In 2007, the first large outbreak of disease caused by Zika virus was reported from the Yap Islands of the Federated States of Micronesia with 185 confirmed cases. During that time the virus moved from south-east Asia across the Pacific.,69

$\triangle \square$ Correspondence:

Professor Dr. S.M. Shamsuzzaman

Department of Microbiology

Dhaka Medical College, Dhaka, Bangladesh

Tel: 01819289739

E-mail: smszaman@yahoo.com
In 2013, another large outbreak was reported in French Polynesia that was thought to be from an independent introduction of the virus from Asia than the Yap Island outbreak..$^{5,9}$ The mosquito Aedes hensilli, which was the predominant species identified in Yap during the outbreak, was probably the main vector of transmission 9,10 Zika virus outbreaks becomes pandemic in 2015 as it occurs in French Polynesia, New Caledonia, the Cook Islands, and Easter Island, Mexico, Central America, the Caribbean, and South America in the same year. ${ }^{5,11}$ Zika virus infection is not a disease for compulsory notification in Brazil, even so, cases were reported in 14 states of the country and mosquito-borne Zika virus is suspected to be the cause of microcephaly and infant deaths in Brazil in 2015. 2,11 Although a very few cases were identified in Asia, but a surge in Latin America has pushed the UN health agency to declare Zika a global health emergency. ${ }^{6,12}$ Sero-surveys indicated a much broader geographic distribution of human infection, including Egypt, East Africa, Nigeria, India, Thailand, Vietnam, the Philippines, Malaysia and few other Asian countries.12 There is no reported case in Bangladesh and India till now but the Aedes aegypti mosquito whose bite transmits the disease, dengue and chikungunya, are widely prevalent in these countries.13 Bangladesh health ministry and IEDCR arranged meeting about global emergence of Zika virus and took decision to prepare guidelines for detection of Zika virus infection in Bangladesh.

\section{Virology}

Zika virus is a member of the family Flaviviridae and the genus is Flavivirus. ${ }^{14,15}$ The Zika virus is a enveloped with a non-segmented positive sense single-stranded RNA molecule 10794 bases long with two non-coding flanking regions known as the $5^{\prime}$ NCR and the $3^{\prime} \mathrm{NCR}^{15,16,17}$. The open reading frame of the Zika virus reads as follows: 5/-C-prM-E-NS1NS2A-NS2B-NS3-NS4A-NS4B-NS5-3/ and codes for a polyprotein that is subsequently cleaved into three structural 
proteins such as, capsid (C), precursor membrane (prM), envelope (E) and seven non-structural proteins (NS), NS1, NS2A, NS2B, NS3, NS4A, NS4B, and NS5 (Fig:1 and fig.2). ${ }^{16,17}$ It contains a nucleocapsid surrounded by a hostmembrane derived lipid bilayer that contains envelope proteins $\mathrm{E}$ and $\mathrm{M}$ (Fig:1). ${ }^{17,18}$ The virion is approximately 40 $\mathrm{nm}$ in diameter with surface projections that measure roughly $5-10 \mathrm{~nm} \cdot{ }^{18,19}$ The surface proteins are arranged in an icosahaedral-like symmetry. ${ }^{20}$ The $\mathrm{E}$ protein composes the majority of the virion surface and is involved in host cell binding and membrane fusion during replication of Zika virus. $^{7,16,19}$

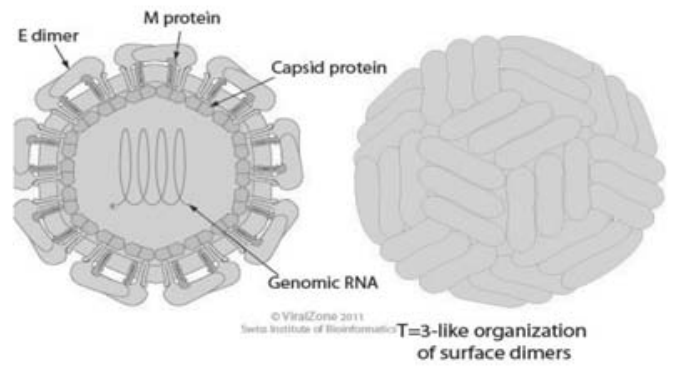

Figure 1: Structure of Zika virus (From internet, available at.http/virazone.expasy.org/all by species/43.html..)

\section{Replicative Cycle of a Zika virus in a Host Cell}

The reproductive cycle of ZIKV follows that of other known flaviviruses. ${ }^{15,18}$ First, the virion attaches to the host cell membrane receptors via the envelope protein which induces virion endocytosis. Next, the virus membrane fuses with the endosomal membrane and the ssRNA genome of the virus is released into the cytoplasm of the host cell. It is then translated into a polyprotein that is subsequently cleaved to form all structural and non-structural proteins. Replication then takes place at intracellular compartments known as cytoplasmic viral factories in the endoplasmic reticulum resulting in a dsRNA genome. The dsRNA genome is then transcribed resulting in additional ssRNA genomes. ${ }^{16,17,20}$ Assembly then occurs within the endoplasmic reiticulum and the new virions are transported to the Golgi apparatus and then excreted into the intracellular space where the new virions can infect new host cells. Flaviviruses generally replicate in the cytoplasm, but Zika antigens have been found in infected cell nuclei. ${ }^{7,16,20}$

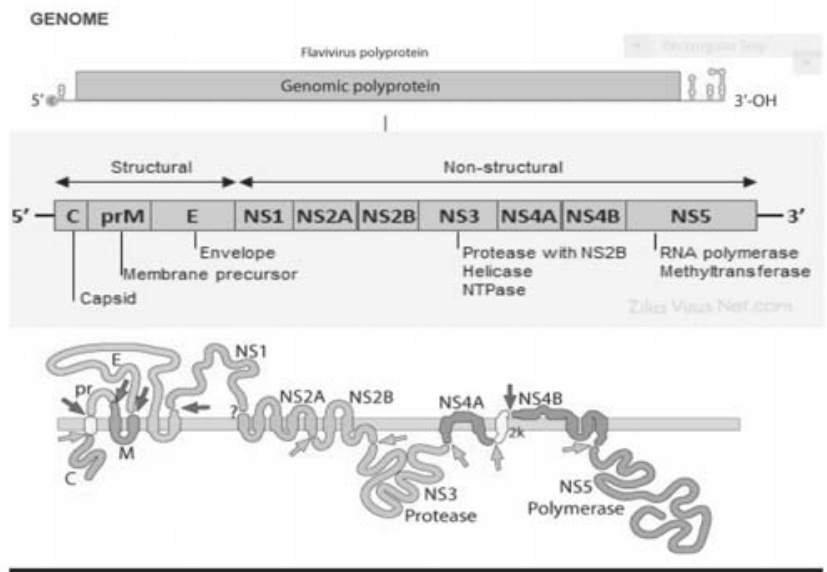

Figure 2: Genome of Zika virus (From internet, available at.http/virazone.expasy.org/all by species/43.html..)

\section{Transmission}

Zika virus is transmitted to people through the bite of an infected mosquito from the Aedes genus, mainly Aedes aegypti and Aedes albopictus and sometimes Ades hensilli. ${ }^{7,16,18}$ This is the same mosquito that transmits dengue, chikungunya and yellow fever.$^{21,22}$ Zika can be transmitted from a man to his sex partners, meaning a person travelled to an area where Zika has broken out, got the virus and gave the virus to sexual partners who did not travel.21 Sexual transmission of Zika virus has been documented in six countries - Argentina, Chile, France, Italy, New Zealand and the United States - during the 2015 outbreak. ${ }^{20,22,23}$ Few cases of Zika virus through blood transfusion have been reported globally. ${ }^{20,24}$ The virus is detected in saliva and in urine in infected person. 19,25,26 The pregnant women who become infected with Zika virus can transmit the virus transplacentally to their unborn babies with potentially serious consequences.$^{21,27}$ To date, there are no reports of infants getting Zika virus through breastfeeding. ${ }^{28}$ In nature, reservoirs for ZIKV virus are restricted to primates. ${ }^{19,20,29}$

\section{Pathogenesis}

Zika replicates in the mosquito's midgut epithelial cells and then its salivary gland cells. After 5-10 days, ZIKV can be found in the mosquito's saliva which can then infect human. $20,30,31$ If the mosquito's saliva is inoculated into human skin, the virus infect epidermal keratinocytes, skin fibroblasts in the skin and the Langerhans cells ${ }^{32}$. The pathogenesis of the virus is hypothesized to continue with a spread to lymph nodes and the bloodstream. ${ }^{33,34}$ Flaviviruses generally replicate in the cytoplasm, but Zika antigens have been found in infected cell nuclei. ${ }^{7,31}$ 


\section{Signs and Symptoms of Zika Fever}

The incubation period of infection is 3 to 12 days and most of the infected persons remain asymptomatic. ${ }^{23,31}$ The majority of infected individuals have minimal symptoms. Symptoms starts with low grade fever which progresses to maculopapular rash which may be itchy, non-purulent conjunctivitis, arthralgia, myalgia, headache, back pain, edema in lower limb and less frequently retro-orbital pain, anorexia, nausea, vomiting, diarrhoea and abdominal pain. 35,36,37 The symptoms last for 4-7 days and are self limiting. ${ }^{38,39}$ There is no evidence that pregnant women are more vulnerable to acquiring Zika infection or that this infection causes a more serious illness in pregnant women. ${ }^{20,33,40}$

\section{Complications}

Serious complications from ZIKV are uncommon. ${ }^{31}$ However, an increase in cases of fetal microcephaly and severe brain anomalies if infected during fetal life . ${ }^{31,41}$ Guillain-Barre syndrome, acute disseminated encephalomyelitis and other neurological and autoimmune syndromes have been reported if, infected after birth or adults in areas where Zika virus infection outbreaks have occurred.4,42 It has been demonstrated that Zika virus can cross the placental barrier and the virus has been detected in blood and tissues of affected foetuses. ${ }^{22,24}$ The full range of birth defects caused by maternal infection is not known, it is also not understood which stage of pregnancy at which the mother became infected affects the fetus and whether other risk factors might exist that affect outcomes. ${ }^{26,38}$ Like other congenital infections such as CMV, rubella and toxoplasmosis, it is likely that ZIKV infection in early pregnancy poses the greatest risk. ${ }^{27,41}$

\section{Diagnosis}

Infection with Zika virus may be suspected based on symptoms developed in person of endemic area for Zika virus infection and who or sex partner has recent history of travel to an area where Zika virus is known to be present. ${ }^{18,42}$ Zika virus diagnosis can only be confirmed by laboratory testing for the presence of Zika virus RNA in the blood or other body fluids, such as urine or saliva by reverse transcription polymerase chain reaction (RT-PCR) tests in 3-5 days after onset of symptoms and remain positive up to 10 days. ${ }^{23,36}$ IgM for ZIKV is typically detectable in 5 days after onset of infection, but cross-reactivity with closely related dengue, yellow fever, Japanese encephalitis, and West Nile viruses are possible. ${ }^{2036}$ Four fold rise or more of neutralizing antibody titre in a paired serum in 2 weeks interval can confirm diagnosis of Zika. ZIKV RT-PCR can also be performed on amniotic fluid although it is currently not known how sensitive or specific this test is for congenital infection. ${ }^{31}$

\section{Treatment and Prevention}

Until now no specific antiviral drug is available to treat Zika viral infection. Zika virus disease is usually relatively mild and requires no specific treatment ${ }^{27,43}$ Symptomatic treatment such as rest, fluids, and paracetamol when require is recommended. ${ }^{19,30}$ Prevention and control relies on reducing mosquitoes through removal and modification of breeding sites and reducing contact between mosquitoes and people. Travellers should take the basic precautions to protect themselves from mosquito bites. ${ }^{38}$ The Aedes mosquito, the vector for $\mathrm{ZIKV}$, is active during daylight hours, bites are most common during mid-morning and late afternoon to dusk, when the mosquito is most active. ${ }^{39,41}$ In the UK, the National Travel Health Network and Centre (NaTHNaC) now advises that pregnant women should consider avoiding travel to countries where ZIKV outbreaks are ongoing, in order to reduce the risk to their babies and to avoid becoming pregnant while travelling in an area with active ZIKV transmission. 27,39 It is advocated by the CDC to use insect repellent, long sleeved-clothing, and intervention in reducing the number of mosquito vectors. Additionally, to avoid sexual transmission, safe sex practices are also encouraged. US FDA, recommended blood donor screening and deferring high risk blood donors for 4 weeks. ${ }^{27,43}$ No vaccine is available now. ${ }^{44}$ Several companies and institutions internationally are developing vaccines against Zika, but none had yet reached clinical trials. ${ }^{22,26,37}$ During the first week of infection, Zika virus can be found in the blood and passed from an infected person to a mosquito through mosquito bites. So, a Zika viral infected patient should be kept away from mosquito bite for the first week of illness. Zika virus does not pass though breast milk, so mothers are encouraged to breastfeed even in areas where Zika virus is found ${ }^{44}$

\section{References:}

1. Dick GW, Kitchen SF, Haddow AJ. Zika virus isolations and serological specificity.Trans R Soc. Trop Med Hyg. 1952; 46:509.

2. Moore DL, Causey OR, Carey DE, Reddy S, Cooke AR, Akinkugbe FM. Arthropod-borne viral infection of man in Nigeria, 1964 -1970. Ann Trop Med Parasitol. 1975;69:49 64.

3. Fagbami AH. Zika virus infections in Nigeria: virological and seroepidemiological investigations in Oyo State. J Hyg (Lond). 1979;83:213-9.

4. Haddow AJ, Williams MC, Woodall JP, Simpson DI, Goma LK. Twelve isolations of Zika virus from Aedes (Stegomyia) africanus (Theobald) taken in and above a Uganda forest. Bull World Health Organ. 1964; 31:57-69. 
5. Cao-Lormeau VM,Roche,TeissierA. Zika virus- French Polynesia, SouthPacific.Emerg Infect Dis.2013;20: 1084-86.

6. Duffy MR, Chen TH, Hancock WT, Powers AM, Kool JL, Lanciotti RS, et al. Zika outbreak on Yap Island, Federated States of Micronesia. N Engl J Med. 2009;360:2536-43.

7. Edward B. Hayes. Zika virus outside Africa. Emerg Infect Dis. 2009 Sep; 15(9): 1347-1350..

8. Epidemiological Alert. Increase of microcephaly in the northeast of Brazil, 2015. PAHO/WHO. Available from http://www.paho.org/hq/index.php.

9. Zanluca C, De Melo VCA, MosimannALP, Dos Santos GIV, Dos Santos CND, LuzK. First report of autochthonous transmission of Zika virus in Brazil. Mem Inst OswaldoCruz2015;110: 569- 72.

10.Kwong JC, Druce JD, Leder K. Zika virus infection acquired during brief travel to Indonesia. Am J Trop Med Hyg. 2013;89:516-7 and. 10.4269/ajtmh.13-0029 PMC free article PubMed Cross Ref.

11. Haddow AD, Schuh AJ, Yasuda CY, Kasper MR, Heang V, et al. (2012) Genetic Characterization of Zika Virus Strains: Geographic Expansion of the Asian Lineage. PLoS Negl Trop Dis 6(2): e1477. doi:10.1371/journal.pntd.0001477

12.Foy BD, Kobylinski KC, Chilson Foy JL, Blitvich BJ, Travassos da Rosa A, Haddow AD. Probable non-vectorborne transmission of Zika virus, Colorado, USA. Emerg Infect Dis. 2011; 17:880-2. 10.3201/eid1705.101939.

13.Rao TR. Distribution, density and seasonal prevalence of aedes aegypti in indian subcontinent and south east asia. Bull World Health Organ. 1967:36(4)547-551.

14.Faye O, Freire C, Iamarino A, Faye O, de Oliveira J, Diallo M, Zanotto P, Sall A. (2014) Molecular Evolution of Zika Virus during Its Emergence in the 20th Century. PLOS Neg Trop Dis. Available from http://dx.doi.org/10.1371/journal .pntd.0002636.

15. Chambers T, Hahn C, Galler R, Rice C. (1990) Flavivirus genome organization, expression, and replication. Annu. Rev. Microbiol. 1990. 44:649-88.

16.Flaviviridae. Swiss Institute of Bioinformatics. Available at.http/virazone.expasy.org/all by species/43.html..

17.Knipe DM, Howley PM. Fields' Virology (5th ed.); 2007: pp 1180-1185.

18.Buckley A. Gould EA. Detection of Virus- specific Antigen in the Nuclei or Nucleoli of Cells Infected with Zika or Langat Virus. J Gen Virol 1988; 69 (8): 1913-19.

19.Shawan MMAK, Hossain MD M, Hasan MD A, Hasan MD M, Pravin A, Akter S, Uddin KR, Banik S, Morshed M, Rahaman MD N, Rahman SM B, Design and Prediction of Potential RNAi(siRNA) Molecules for 3'UTR PTGS of different Strains of Zika Virus: A
Computational Approach. Nature and Science.2015; 13(2).

20.Zika Virus -Structure, Genome, Symptoms, Trasmission, Pathogenesis, Diagnosis. 2015. Available from http://www.microbiologyinfo.com/zika-virus-structure-genomesymptoms-transmission-pathogenesis-diagnosis/html.

21.Musso,D, Roche, C, Robin, E, Nhan, T,, Teisser, A, and Cao-Lormeau, VM. Potential sexual transmission of Zika virus. Emerg Infect Dis, 2015; 21(2): 359-61.

22.Clinical advice on Zika: assessing pregnant women following travel; symptoms, transmission (includes sexual transmission), Epidemiology. Health protection -guidance Zika virus - EU Referendum. December 2015. Available from https://www.gov.uk/guidance/zika-virus.

23.Frequently Asked Questions Zika Fever (Zika Virus Infection) .Ministry of Health, Jamaica. Final MBD 2015. Available from http://jis.gov.jm/media.

24. Musso D, Nhan T, Roche C, Robin E, Bierlaire D, Zisou K, Yan A S, Cao-Lormeau VM, Broult J, Potential for Zika virus transmission through blood transfusion demonstrated during an outbreak in Frenchs Polynesia, November 2013to February 2014. Euro Surveill. 2014 Apr 10;19(14): pii 20761

25.Junior VLP, Luz K, Perreeira R, Ferrinho P.Zika virus: A Review to Clinicians. Website . 2015; 28 (6): 760-765

26. Center for Disease Control and Prevention. Zika fever in Cook Islands. April 2014. Available from http://wwwnc.cdc.gov/travel/notices/watch/zika-fevercook-islands.

27.Besnard M, Lastere S, Teisser A, Cao-Lormeau VM, Musso D,Evidence of perinatal transmission of Zika virus, French Polynesia, Dec. 2013 and February 2014. Euro Surviill 2014;19:13-6.

28.Thomas C. Zika virus : Transmission \& Prevention, Symptoms \& Treatment. December 2015. Available from http://www.disabled-world.com/health/zika.php.

29.Hamel R, Dejarnac O, Wichit S, Ekchariyawat P, Neyret A, Luplertlop N, Perera-Lecoin M, Surasombatpattana P, Talignani L, Thomas F, Cao-Lormeau V-M, Choumet V, Briant L, Desprès P, Amara A, Yssel H, Missé D. 2015. Biology of Zika virus infection in human skin cells. J Virol 89:8880 -8896. doi:10.1128/JVI.00354-15

30.Darwish M, Hoogstraal H, Roberts T, Ahmed I, Omar F. A sero-epidemiological survey for certain arboviruses (Togaviridae) in Pakistan. Trans R.soc Trop. Med Hyg 183; 77(4): 442-5

31.Musso D, Lormeau VMC, Gubler DJ. Zika virus: following the Path of dengue and Chikungunya. The Lancet, 2015; 386 (9990): 243-244.

32.Hamel R, Dejarnac O, Wichit S, Ekchariyawat P, Neyret A, Luplertlop N, Perera-Lecoin M, Surasombatpattana P, 
Talignani L, Thomas F, Cao-Lormeau V-M, Choumet V, Briant L, Desprès P, Amara A, Yssel H, Missé D. 2015. Biology of Zika virus infection in human skin cells. J Virol 89:8880 -8896. doi:10.1128/JVI.00354-15.

33. Diamond MS, ShresthaB, Meahlhop E, Sitati-E, Engle-M. Innate and Adaptive immune responses determine protection against disseminated infection by WestNile encephalitis . Viral immunol. 2003; 16:259-78.

34.Center for Disease Control and Prevention. Zika fever in Cook Islands. April 2014. Available from http://wwwnc.cdc.gov/travel/notices/watch/zika-fevercook-islands.

35.Microcephaly in Brazil potentially linked to the Zika virus epidemic. Rapid risk assessment. November 2015. European Centre for Disease Prevention and Control, Stockholm, 2015. Available from Europa.eu/eu/Publications/zika-mic.

36.Lanciotti, Rs, Kosoy, OL, Laven, JJ, Velenz, JO, Lambert, AJ, Johnson, AJ, Stanfield, SM, and Duffy, MR, Genetic and Serological properpities of Zika virus associated wiyh an epidemic, Yap State, Mcronesia, 2007, Emerg Infect Dis,2008 14 (8):1232-9.

37.Mallet H-P Emergence du virus Zika en Polynesie Francaise.In:15eme journees nationals d, infection.editor. Bordeaux-France, 2014; p28.

38. Oehler E, Watrin L, Larre P, Leparc-Goffart I, Lastere S, Valour F, et al. Zika virus infection complicated by
Guillain-Barré syndrome - case report, French Polynesia, December 2013. Euro Surveill. 2014 Mar 6;19(9): pii $=20720$

39. Mallet H, Berry A. Emergence du virus Zika en Polynesie Francaise Nov 2013-April2014.Bulletin de veille Sanitarie Antilles.201;9-12.

40.Shapsshak P, Somboonwit C, BrianT, Foley, Sally F. Alrabaa, Todd Wills and Jonh T. Sinnott. Global Virology I - Identifying and Investigating Viral Diseases htts:/ books google. Com.books.2015.

41.Grad G, Caron M, Mombo I, Nikoghe D,Mboui ondo S,Jiolle D, et al, Zika in gabon ( Central Africa) 2007: A new Threat from Aedes albopictus? PLOS Negl Trop Dis, 2014; 8(2): e2681.

42. Mallet H-P Emergence du virus Zika en Polynesie Francaise.In:15eme journees nationals d, infection.editor. Bordeaux-France, 2014; p28.

43.Lederman JP, Guillaumot L, Yug L Saweyog SC, Tided M Machieng P, et al, Aedes hensilli as a potential vector of Chikungunya and viruses. PLOS Negl Trop Dis, 2014; 8(10): e3188

44.Thomas C. Zika virus : Transmission \& Prevention, Symptoms \& Treatment. December 2015. Available from http://www.disabled-world.com/health/zika.php. 